\title{
INSTALASI PLTS SKALA RUMAH TANGGA DENGAN LAMPU LED DC HEMAT ENERGI BAGI MASYARAKAT TERPENCIL DI KABUPATEN KUBU RAYA, KALIMANTAN BARAT
}

\author{
Nelly Wahyuni ${ }^{1}$, Syaifurrahman ${ }^{2}$, Jamhir Islami ${ }^{3}$ \\ 1Universitas Tanjungpura. Email: nellywahyuni@chemistry.untan.ac.id \\ ${ }^{2}$ Universitas Tanjungpura. Email: syaifur_rahman@yahoo.com \\ 3Universitas Tanjungpura. Email:4170nk@gmail.com
}

\begin{abstract}
Electrical energy needs are very important for villagers' activities in improving work productivity and education. For people who live in remote areas, such as Sepok Keladi, Sungai Kakap sub-district, Kubu Raya district, fulfilling electricity is a big problem. Because the PLN electricity network has not reached the area. Therefore, the most appropriate solution to overcome the absence of electrical energy in this area is to convert sunlight into electrical energy using photovoltaic technology (Solar Cells). The system for supplying electricity with this system is called the Solar Power Plant (PLTS). Currently, PLTS is still classified as a power plant with an expensive initial investment. Therefore, installing PLTS is preferred for lighting. For these purposes, the use of lamps that require low power is very important. Energy-saving light Emitting Diode (LED) DC lights are one solution that can be applied to overcome lighting problems in remote areas that receive energy supplies from PLTS. With lighting, it can support social, economic and community education activities, especially at night.
\end{abstract}

Keywords: PLTS, remote areas, LED lights, energy-saving.

\begin{abstract}
ABSTRAK
Kebutuhan energi listrik sangat penting bagi aktivitas warga desa dalam meningkatkan produktivitas kerja dan pendidikan. Bagi masyarakat yang tinggal di daerah terpencil, seperti dusun Sepok Keladi, kecamatan Sungai Kakap kabupaten Kubu Raya, pemenuhan akan energi listrik merupakan masalah besar. Oleh karena jaringan listrik PLN belum menjangkau daerah tersebut. sehingga solusi yang paling tepat untuk mengatasi ketiadaan energi listrik di daerah tersebut adalah dengan mengubah cahaya matahari menjadi energi listrik menggunakan teknologi photovoltaic (Sel Surya). Sistem penyediaan energi listrik dengan sistem ini disebut Pembangkit Listrik Tenaga Surya (PLTS). Saat ini PLTS masih digolongkan sebagai pembangkit listrik dengan investasi awal yang mahal, Oleh karena itu, pemasangan PLTS lebih diutamakan untuk penerangan. Untuk keperluan tersebut penggunaan lampu yang memerlukan daya rendah sangatlah penting. Lampu light Emitting Diode (LED) DC hemat energi merupakan salah satu solusi yang dapat diterapkan untuk mengatasai masalah penerangan di daerah terpencil yang mendapat suplay energi dari PLTS. Dengan adanya penerangan dapat menunjang aktivitas sosial, ekonomi dan pendidikan masyarakat terutama pada malam hari.
\end{abstract}

Kata Kunci: PLTS, daerah terpencil, Lampu LED, hemat energi

\section{PENDAHULUAN}

Berdasarkan data yang dikeluarkan oleh PLN, sampai akhir tahun 2018, elektrifikasi di Kalimantan Barat sebesar 87\% (PLN, 2019). Dari 2.130 desa yang ada, rasio yang berlistrik PLN 71,13\% (www. ekonomibisnis). Dengan demikian, 29\% 
wilayah-wilayah masih belum mendapat akses listrik dari PLN. Salah satu kendala adalah akses wilayah yang tidak dapat dilalui melalui jalur darat.

Dusun Sepok Keladi (Gambar 1) merupakan salah satu wilayah di Kalimantan Barat yang menghadapi masalah tersebut. Dusun Sepok Keladi merupakan daerah terpencil di kecamatan Sungai Kakap kabupaten Kubu Raya dengan jumlah kepala keluarga sebanyak 32 kepala keluarga. Hampir semua warga di Sepok Keladi bekerja sebagai nelayan atau agen ikan pengumpul ikan, dengan tingkat ekonomi menengah ke bawah. Dusun Sepok Keladi merupakan kawasan desa binaan Universitas Tanjungpura khususnya untuk masalah energi listrik dan air bersih.

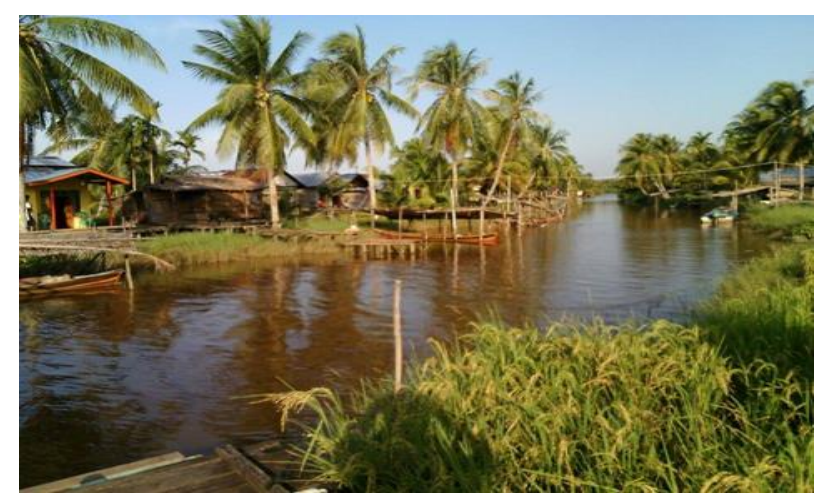

Gambar 1. Dusun Sepok Keladi

Salah satu upaya dalam mengatasi energi listrik adalah memasang pembangkit listrik tenaga surya (PLTS) karena sangat sesuai dengan geografis yang berada di lintasan khatulistiwa (Alfanz, dkk., 2015). Potensi intensitas radiasi matahari di wilayah khatulistiwa cukup tinggi dan merata yaitu 4,5kWh/m² (Dewantoro \& Priyatman, 2015). PLTS sangat cocok untuk wilayah-wilayah terpencil yang tidak dapat (sulit) ditempuh melalui darat dan jauh dari pusat pembangkit listrik. Selain itu karena pembangkit listrik ini mempunyai banyak keuntungan seperti ramah lingkungan, fleksibel untuk pengembangan kapasitas daya tidak tergantung dari sumber energi fosil (Djamin, 2010).

Saat ini Pembangkit listrik tenaga surya (PLTS) masih digolongkan sebagai pembangkit listrik dengan investasi awal yang besar (Dewantoro \& Priyatman, 2015). Besarnya investasi PLTS dikarenakan peralatan/perangkat panel surya dibutuhkan masih sangat mahal. Oleh karena itu, pemasangan PLTS lebih diutamakan untuk penerangan.

Gambar 2. memperlihatkan diagram blok intalasi PLTS skala rumah tangga. Dengan beban lampu LED sebanyak 4 buah ( $\left.\mathrm{L}_{1}-\mathrm{L}_{4}\right)$. Panel surya berfungsi untuk mengubah intensitas cahaya matahari menjadi energi listrik. Panel surya yang digunakan memiliki kemampuan 50 Wp dengan dimensi $75 \mathrm{~cm} \times 50 \mathrm{~cm}$, tegangan maksimum $21 \mathrm{~V}$ dan arus maksimum 2,8 A. Solar charger controller berfungsi untuk memberikan kestabilan tegangan pengecasan, mendeteksi beban lebih, pengecasan lebih dan arus hubung singkat. 


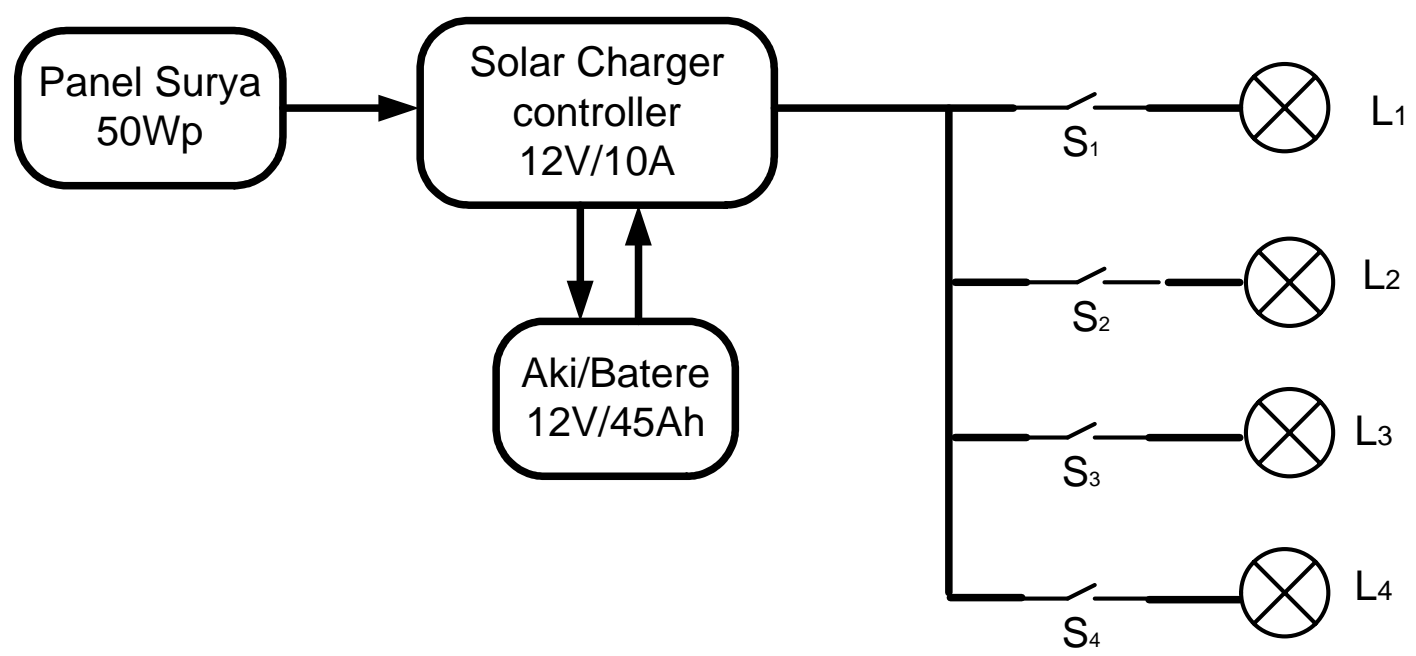

Gambar 2. Diagram blok Instalasi PLTS rumah tangga

Kebutuhan energi listrik sangat penting bagi aktivitas warga desa dalam meningkatkan produktivitas kerja dan pendidikan (S Kumara, 2010). Salah satu komponen utama dalam sistem penerangan adalah lampu. Untuk itu perlu dilakukan instalasi PLTS mengunakan lampu DC hemat energi yang mudah dalam penggunaan dan murah operasional serta perawatannya. Pada kegiatan pengabdian pada masyarakat ini akan digunakan lampu LED (Light Emitting Diode) DC hasil rancangan dari peneliti Universitas Tanjungpura.

Lampu LED DC merupakan terobosan baru pada sistem penerangan dan memiliki beberapa keunggulan dibanding lampu LHE neon, seperti daya rendah, intensitas cahaya lebih terang dan masa pakai lebih lama dan harga yang tidak jauh berbeda dengan lampu lain (Saputro, Sukmadi, \& Karnoto, 2013). Lampu LED DC dapat disuply dengan tegangan DC dari batere/aki sehingga sangat cocok untuk penerangan pada pembangkit listrik tenaga surya. Penggunaan lampu LED DC dapat mengurangi satu bagian/peralatan pada PLTS, yaitu inveter sehingga biaya menjadi lebih murah. Inverter merupakan suatu alat yang mengubah besaran listrik dari DC menjadi AC (sama dengan jala-jala PLN) dimana penggunaannya dapat mengurangi daya pada PLTS. Penggunaan lampu LED DC hemat energi yang terintegrasi dengan PLTS diharapkan dapat menyelesaikan masalah kelistrikan terutama untuk penerangan daerah terpencil di Kalimantan Barat yang belum tersentuh jaringan listrik PLN.

\section{METODE PELAKSANAAN}

Kegiatan pengabdian pada masyarakat ini dilaksanakan di dusun Sepok Keladi, kecamatan Sungai Kakap, Kabupaten Kubu Raya, Kalimantan Barat. Kegiatan ini melalui beberapa tahapan yaitu: 1 . Survey lokasi untuk menentukan lokasi pemasangan PLTS dan jumlah lampu yang diperlukan untuk setiap rumah, 2. Perakitan lampu LED DC di laboratorium elektronika dasar Universitas Tanjungpura, 3. Pemasangan instalasi PLTS menggunakan lampu LED DC, dan 4. Pelatihan kepada warga tentang instalasi dan perawatan PLTS serta lampu LED DC. 


\section{HASIL DAN PEMBAHASAN}

Ada dua bentuk lampuLED DC yang dibuat yaitu bentuk yang pertama lampu LED menggunakan down ligth, dan kedua lampu LED menggunakan cassing lampu (Gambar 3). Lampu LED DC yang dibuat dengan menggunakan down light sebagai reflektor agar cahaya lebih terarah.

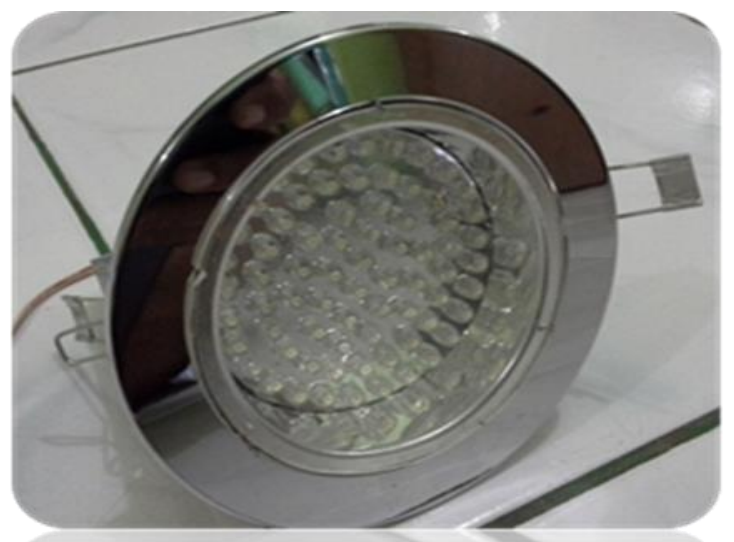

LED ultra bright

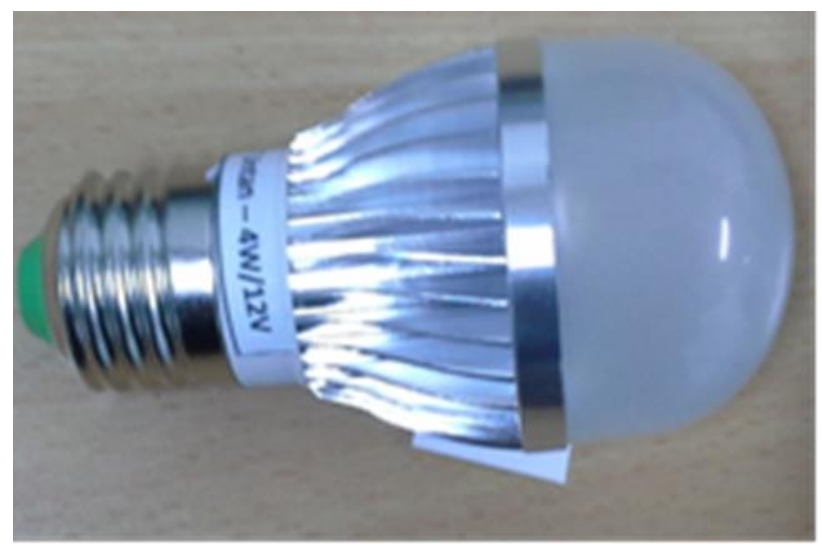

LED dengan cassing lampu

Gambar 3. Lampu LED DC hemat energi

Lampu DC hemat energi dapat memancarkan cahaya terang dengan daya rendah (3W). (Gambar 4). Lampu DC ini digerakkan dengan rangkaian multivibrator yang dapat menghasilkan pulsa penyalaan dengan frekuensi tinggi. Lampu akan menyala secara bergantian, karena frekuensi tinggi nyala lampu kelihatan sama. Lampu ini sangat cocok digunakan untuk solar home system karena memerlukan daya rendah (Saputro, Sukmadi, \& Karnoto, 2013).
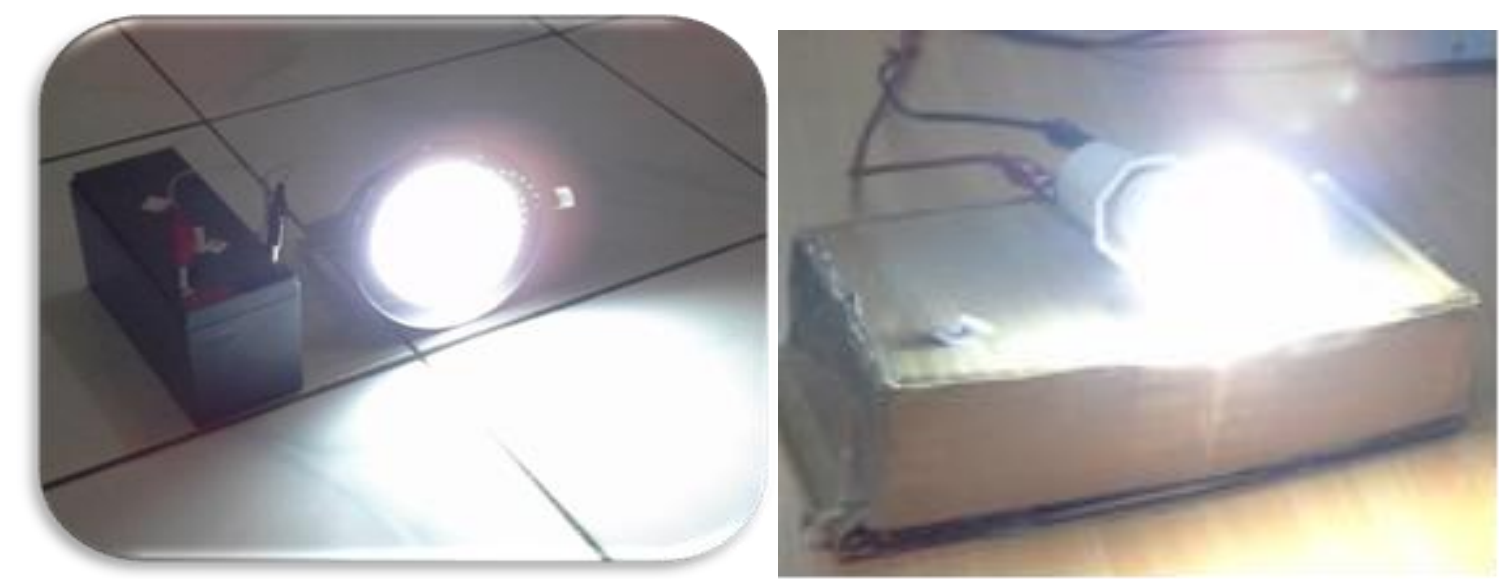

Gambar 4. Nyala lampu LED DC hemat energi dengan aki 12V

Karakteristik arus dan intensitas cahaya pada lampu LED komersial dengan merk tertentu serta lampu DC Hemat energi ditampilkan pada Tabel 1. Lampu yang dijual di pasaran atau komersial yang diukur yaitu memiliki ukuran daya 5W, 7W dan 9W. 
Tabel 1. Pengukuran besaran listrik lampu LED komersil dan LED DC hemat energi

\begin{tabular}{cccccc}
\hline & & Lampu komersil & \multicolumn{2}{c}{ Lampu LED DC hemat energi } \\
\hline $\begin{array}{c}\text { Daya } \\
(\mathbf{W})\end{array}$ & $\begin{array}{c}\text { arus } \\
\text { (mA) }\end{array}$ & $\begin{array}{c}\text { intensitas cahaya } \\
\text { (Lumen) }\end{array}$ & $\begin{array}{c}\text { Daya lampu hasil } \\
\text { perhitungan(W) }\end{array}$ & Daya (W) & $\begin{array}{c}\text { Rata-rata } \\
\text { (Lumen) }\end{array}$ \\
\hline 5 & 300 & 85 & 3,6 & $\mathbf{3}$ & 140 \\
\hline 7 & 370 & 120 & 4,44 & 4 & 149 \\
\hline 9 & 420 & 135 & 5,04 & 6 & 260 \\
\hline
\end{tabular}

Tabel 1 menunjukkan lampu dengan daya 5W memberikan intensitas cahaya 85 lumen, jika dibandingkan dengan lampu LED DC yang dibuat lampu 3W dengan enam LED memberikan rata-rata intensitas cahaya 140 lumen. Hal ini berarti intensitas cahaya untuk lampu 3W rakitan lebih tinggi dengan lampu 5W pabrikan atau komersial. Berdasarkan hasil perhitungan daya terhadap lampu 5W pasaran hanya sebesar 3,6W. Dengan demikian lampu LED DC memiliki intensitas lebih baik dibanding lampu komersial, sehingga cocok digunakan untuk lampu penerangan pada sistem PLTS.

\section{Instalasi PLTS dengan lampu DC hemat energi}

Pemasangan Instalasi PLTS dilakukan pada salah satu rumah di Sepok Keladi dan surau dengan daya panel masing- masing sebesar 50Wp (Gambar 5). Untuk panel 50Wp dapat memberikan daya terpakai sebesar 30 Watt khusus untuk penerangan selama 12 jam dalam satu hari.

Solar charger controller memiliki kemampuan tegangan $12-24 \mathrm{~V}$ dengan arus pengecasan maksimum 10A sehingga dapat melayani maksimum beban hingga 120 Watt. Aki yang digunakan pada PLTS ini adalah aki kering bebas perawatan dengan spesifikasi tegangan $12 \mathrm{~V}$ dan $45 \mathrm{Ah}$. Secara teoritis aki ini dapat mensuply energi hingga 540 Watt-hour. Namun penggunaan aki tidak boleh sampai kering, karena dapat merusak fungsi aki sebagai tempat penyimpan muatan, secara teoritis pemakaian energi aki atau depht of Discharge (DOD) maksimal adalah setengah dari energi maksimum atau $50 \%$ saja (Roal, 2015).

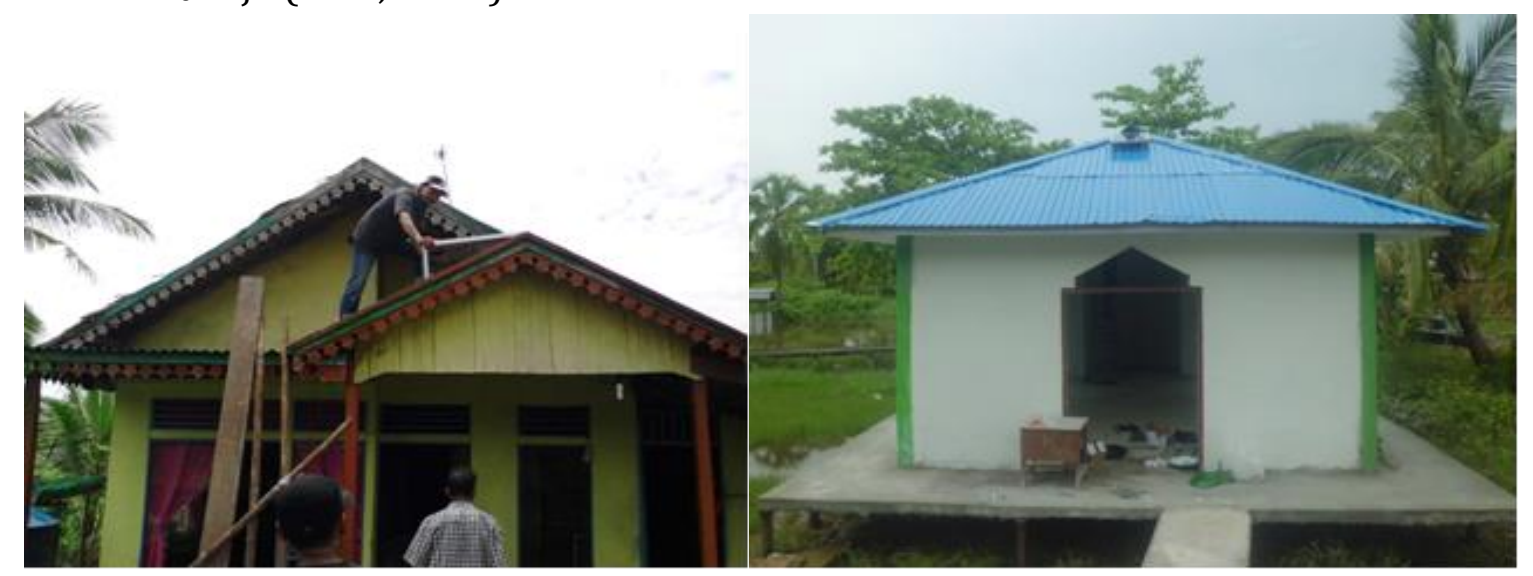

Gambar 5. Pemasangan panel surya di rumah warga dan surau

Untuk penerangan rumah, beban listrik menggunakan 4 buah lampu LED DC untuk empat ruangan yaitu ruang tamu ruang tengah/dapur, kamar tidur dan teras rumah/jalan (Gambar 6). Berdasarkan hasil perhitungan daya PLTS dengan penyinaran 
normal 7 jam/hari panel surya $50 \mathrm{Wp}$ dan aki 45 Ah dapat mensuplay beban 15 watt selama 12 jam setiap harinya atau pemakaian energi sebesar 180 Watt-hour. Dengan demikian untuk penerangan setiap rumah dapat menggunakan lampu LED DC 3 watt.

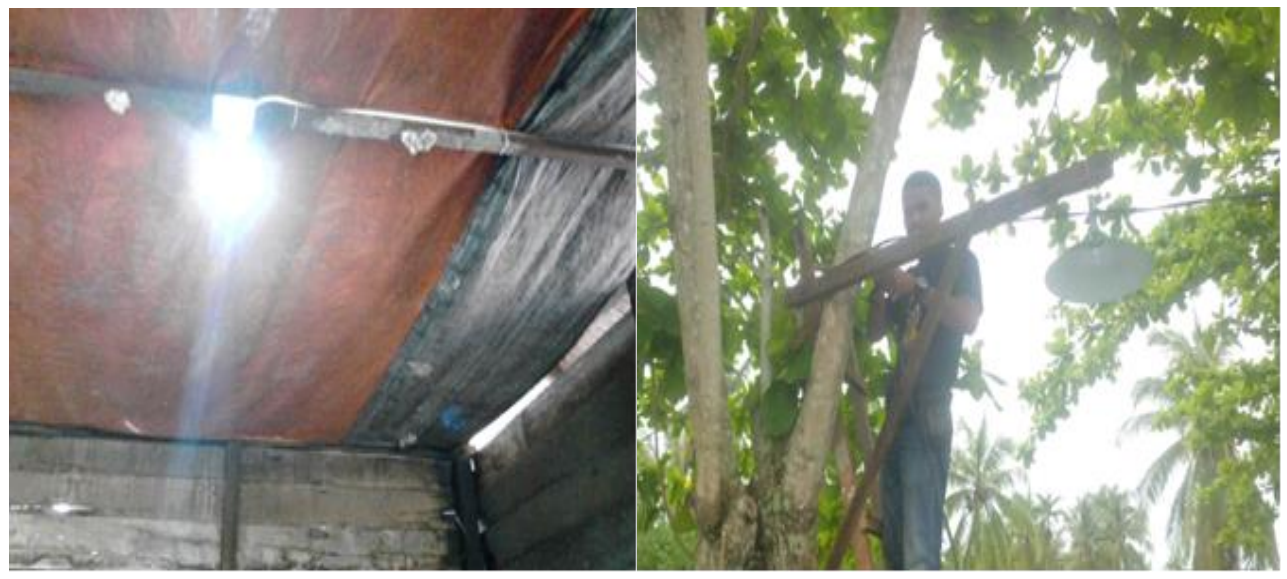

Gambar 6. Lampu LED DC di salah satu rumah dan penerangan jalan

\section{SIMPULAN}

Permasalahan penerangan di daerah pesisir terutama dusun Sepok Keladi dapat diselesaikan menggunakan pembangkit listrik tenaga surya (PLTS) menggunakan lampu DC hemat energi. Sistem ini dapat dilakukan di daerah-daerah lain yang memiliki kendala yang sama. Penggunaan lampu LED DC dapat menghemat penggunaan daya listrik, sehingga lebih hemat energi. Dengan adanya penerangan di Dusun Sepok Keladi dapat menunjang aktivitas sosial, ekonomi dan pendidikan masyarakat terutama pada malam hari.

\section{UCAPAN TERIMA KASIH}

Ucapan terima kasih disampaikan kepada Direktorat Jenderal Pendidikan Tinggi, Kementrian Riset, Teknologi dan Pendidikan Tinggi, melalui DIPA Universitas Tanjungpura yang telah mendanai kegiatan pengabdian masyrakat ini. Kegiatan ini merupakan bagian dari skema hibah Fundamental Aplikatif.

\section{DAFTAR RUJUKAN}

Alfanz, R., K. Maulana, F., \& Haryanto, H. (2015). Rancang bangun penyedia energi listrik tenaga hibrida (PLTS-PLTB-PLN) untuk membantu pasokan listrik rumah tinggal. Setrum, 4(2), 34-42.

Dewantoro, A. P. \& Priyatman, H. (2015). Kajian ekonomis energi listrik tenaga surya desa tertinggal terpencil. Jurnal Suara Teknik Fakultas Teknik UMP Pontianak, 1-5.

Djamin, M. (2010). Penelitian penerapan pembangkit listrik tenaga surya dan dampaknya terhadapap lingkungan. Jurnal Teknil Lingkungan, 11(2), 221-225.

https://ekonomi.bisnis.com. Diakses 28 Juli 2019.

PLN. (2019). Diseminasi RUPTL 2019-2028 PT PLN (Persero). 
Roal, M. (2015). Peningkatan Efisiensi Energi Menggunakan Baterai Dengan Kendali Otomatis Penerangan Ruang Kelas Berbasis PLTS. Jurnal ELKHA, 7(2), 12-19.

S Kumara, N. (2010). Pembangkit listrik tenaga surya skala rumah tangga urban dan ketersediannya di Indonesia. Teknologi Elektro, 9(1), 68-75.

Saputro, J. H., Sukmadi, T., \& Karnoto. (2013). Analisa penggunaan lampu LED pada penerangan dalam rumah tangga. Trasmisi, 15(1), 20-37. 
24 J-Abdipamas, Vol. 3, No. 2 Oktober, 2019 